Journal of Biotechnology 17(4): 729-737, 2019

\title{
CHARACTERIZATION OF THE C-TYPE LECTIN FROM THE MARINE SPONGE (STYLISSA FLEXIBILIS)
}

\section{Le Dinh Hung ${ }^{\bowtie}$, Dinh Thanh Trung}

Nha Trang Institute of Technology Research and Application, Vietnam Academy of Science and Technology

${ }^{\circledR}$ To whom correspondence should be addressed. E-mail: ledinhhungims@yahoo.co.uk

Received: 27.11 .2019

Accepted: 25.12.2019

SUMMARY

A lectin from the marine sponge Stylissa flexibilis, designated as SFL, was purified by cold ethanol precipitation followed by ion exchange chromatography on DEAE Sepharose column and Sephacryl S-200 gel filtration. SFL is a dimeric glycoprotein of $32 \mathrm{kDa}$ subunits linked by a disulfide bridge with a molecular mass of $64 \mathrm{kDa}$ by SDS-PAGE and $65 \mathrm{kDa}$ by Sephacryl S-200 gel filtration chromatography. The lectin preferentially agglutinated enzyme treated human A erythrocytes, whereas it did not agglutinate any type of rabbit, human $\mathrm{B}$ and $\mathrm{O}$ erythrocytes, irrespective of treatment with enzymes. The hemagglutination activity of lectin was strongly inhibited by monosaccharide, D-galactose and glycoproteins, asialo-porcine stomach mucin and asialo-fetuin, indicating that lectin is specific for O-glycans. Activity of SFL was stable over a range of $\mathrm{pH}$ from 5 to 8 , up to $60{ }^{\circ} \mathrm{C}$ for $30 \mathrm{~min}$ and its activity was $\mathrm{Ca}^{2+}$ dependent, indicating that SFL was belonged to the C-type lectin family and requires metal for biological activity. SFL caused agglutination of Vibrio alginolyticus and $V$. parahaemolyticus in a dose dependent manner and inhibited the growth rate of these bacterial strains, suggesting that the lectin caused the agglutination through binding to the target receptor(s) on the surface of Vibrios. Thus, SFL can be considered as a good source of lectin(s) being useful as carbohydrate probe and antibacterial reagent.

Keywords: Stylissa flexibilis, antibacterial activity, carbohydrate binding specificity, lectin, marine sponge

\section{INTRODUCTION}

Lectins, or carbohydrate-binding proteins, are present in various organisms from viruses to mammals and serve as recognition molecules between cells, cell and matrix, and organisms. Owing to the capability of discriminating carbohydrate structures, not only are lectins used as valuable biochemical reagents in many research fields, including glycomics, but they also are promising candidates for medicinal and clinical application (Sharon, Lis, 2003).

Recently, a large number of lectins from marine sponges possessing various biochemical characteristics have been purified and identified including: galectins, C-type, tachylectin-like and Ftype lectins (Gardères et al., 2015). Like other natural products isolated from marine organisms, lectins from marine sponges have shown great potential as candidates for new drugs, due to their wide range of biological activities, such as pro- inflammatory and antitumoral (Kawsar et al., 2011; Queiroz et al., 2009), mitogenic (Atta et al., 1989; Bretting et al., 1981a; Xiong et al., 2006; Dresch et al., 2012), chemotactic (Dresch et al., 2008; Queiroz et al., 2008), cytotoxic properties (Pajic et al., 2002), antibacterial activities (Schröder et al., 2003) and antiprotozoan effects against Leishmania chagasi (Moura et al., 2006; Medeiros et al., 2010). Thus, marine sponges may be dominant sources of useful lectins for basic research and applications.

Furthermore, antibacterial activities have been reported for lectins from various biological sources (Santi-Gadelha et al., 2006; Charungchitrak et al., 2011; Schröder et al., 2003; Moura et al., 2006; Kawsar et al., 2011). However, little is known about the effects of lectins from marine organisms towards marine vibrios, except the species-specific activities against vibrios have been reported for the lectins from the red algae, such as ESAs from Eucheuma serra and GMA from Galaxaura marginata (Liao et al., 2003), EDAs from Eucheuma denticulatum (Le 
Dinh Hung et al., 2015a), KSAs from Kappaphycus striatum (Le Dinh Hung et al., 2015b) and GPE from Gracilaria fisheri (Boonsri et al., 2017). Marine vibrios are halophilic Gram-negative proteobacteria, which occupy a diverse range of ecological niches including sediments, water column, and in association with organisms either as symbionts or pathogens (Tracy et al., 2007). It is an economically important disease of fish, marine invertebrates and is responsible for high mortality rates in aquaculture worldwide (Marhual et al., 2010). Among the Vibrios, Vibrio alginolyticus and $V$. parahaemolyticus are quite important, since it causes serious episode to marine fish and shellfish including shrimp (Zorrilla et al., 2003; Marhual et al., 2010). In Vietnam, $V$. alginolyticus, $V$. parahaemolyticus and $V$. harveyi reduced greatly yields of farmed shrimps (FAO, 2013). Thus, the objective of this research was to report on the isolation, biochemical properties, carbohydrate-binding specificity and biological effect including the antibacterial activities against the shrimp pathogenic vibrios of the lectin from marine sponge $S$. flexibilis for future applications.

\section{MATERIALS AND METHODS}

\section{Materials}

Marine sponge Stylissa flexibilis (Lévi, 1961) was collected at the Vinh Hy bay $\left(108^{\circ} 59^{\prime} 27^{\prime \prime} \mathrm{E}\right.$, $\left.11^{\circ} 34^{\prime} 39^{\prime \prime} \mathrm{N}\right)$, Ninh Thuan Province, Vietnam, in April, 2016, brought to the laboratory, and kept at $20{ }^{\circ} \mathrm{C}$ until used. The marine sponge samples were identified by MSc. Thai Minh Quang - Institute of Oceanography, Vietnam. Prepacked columns used were purchased; Sephacryl S-200 $(1.6 \times 60 \mathrm{~cm})$ and DEAE Sepharose fast flow ion exchange chromatographic column $(1.6 \times 20 \mathrm{~cm})$ from GE Healthcare (Sweden). Blood from rabbit was obtained from the Institute of Vaccine Nha Trang, Vietnam and human A, B, and O bloods from Khanh Hoa General Hospital, Vietnam. L-fucose, Dglucose, D-mannose, D-galactose, N-acetyl-Dglucosamine, $\mathrm{N}$-acetyl-D-mannosamine, $\mathrm{N}$-acetyl-Dgalactosamine, transferrin, fetuin, porcine thyroglobulin, and porcine stomach mucin were purchased from Sigma Chemical Co. Yeast mannan and $\mathrm{N}$-acetyl-neuraminic acid was from Nakarai Chemical Co. Three species of shrimp pathogenic Vibrios, Vibrio alginolyticus, $V$. harveyi and $V$. parahaemolyticus were obtained from Research Institute for Aquaculture No. 3, Vietnam.

\section{Extraction and purification of lectin}

Specimens were ground to a fine powder and extracted with $50 \mathrm{mM}$ Tris- $\mathrm{HCl}$ buffer $(\mathrm{pH} 7.5)$ containing $150 \mathrm{mM} \mathrm{NaCl}$ (TBS) for $6 \mathrm{~h}$ at $4^{\circ} \mathrm{C}$. After filtration through a cheese cloth, the filtrate was centrifuged at $3500 \times \mathrm{g}$ for $30 \mathrm{~min}$ at $4^{\circ} \mathrm{C}$. To the supernatant, cold absolute ethanol $\left(-20^{\circ} \mathrm{C}\right)$ was added to attain a final concentration of $80 \%$ and the mixture was kept at $4{ }^{\circ} \mathrm{C}$ overnight. The resulting precipitates were collected by centrifugation at $3500 \times \mathrm{g}$ for $30 \mathrm{~min}$ at $4^{\circ} \mathrm{C}$ and thoroughly dialyzed against $20 \mathrm{mM}$ Tris- $\mathrm{HCl}$ buffer (TB), $\mathrm{pH}$ 7.5. The non-dialyzable fraction was applied to a DEAE Sepharose fast flow ion exchange chromatographic column $(1.6 \times 20 \mathrm{~cm})$, equilibrated with the above buffer. After elution of unbound proteins and pigments in $\mathrm{TB}$, column was eluted with $0.5 \mathrm{M} \mathrm{NaCl}$ in $20 \mathrm{mM}$ Tris-HCl buffer, $\mathrm{pH}$ 7.5; the active fractions were pooled, concentrated by ultrafiltration, and dialyzed against $50 \mathrm{mM}$ Tris- $\mathrm{HCl}, 150 \mathrm{mM}$ $\mathrm{NaCl}$ buffer ( $\mathrm{pH} 7.5$ ). The concentrate was subjected to gel filtration on a Sephacryl S-200 column $(1.6 \times 60 \mathrm{~cm})$ and eluted with the same buffer. The eluate was monitored at absorbance of $280 \mathrm{~nm}$ for protein and for hemagglutination activity with trypsin-treated human A erythrocytes. Active fractions were pooled for further analysis (Moura et al., 2006).

\section{Preparation of a $2 \%$ suspension of native or enzyme-treated erythrocytes}

Each blood sample was washed three to five times with 50 volumes of $150 \mathrm{mM} \mathrm{NaCl}$. After washing, a $2 \%$ erythrocyte suspension $(\mathrm{v} / \mathrm{v})$ was prepared in $150 \mathrm{mM} \mathrm{NaCl}$ and used as native erythrocytes. Trypsin- or papain-treated erythrocytes were prepared as follows. One-tenth volume of $0.5 \%$ $(\mathrm{w} / \mathrm{v})$ trypsin or papain solution was added to a $2 \%$ native erythrocyte suspension, and the mixture was incubated at $37^{\circ} \mathrm{C}$ for $60 \mathrm{~min}$. After incubation, the erythrocytes were washed three to five times with saline and a $2 \%$ suspension $(\mathrm{v} / \mathrm{v})$ of trypsin- or papain-treated erythrocytes was prepared in saline (Le Dinh Hung et al., 2009).

\section{Hemagglutination assay}

Hemagglutination assays were carried out using a microtiter method in a 96-well microtiter V-plate (Le Dinh Hung et al., 2009). First, $25 \mu \mathrm{L}$ amounts of serially two-fold dilutions of a test solution were prepared in $50 \mathrm{mM}$ Tris- $\mathrm{HCl}, 150 \mathrm{mM} \mathrm{NaCl}$ buffer (pH 7.5) containing $20 \mathrm{mM} \mathrm{CaCl}_{2}$ on a microtiter $\mathrm{V}$ - 
plate and incubated at room temperature for $1 \mathrm{~h}$. To each well, $25 \mu \mathrm{L}$ of a $2 \%$ erythrocyte suspension was added and the mixtures gently shaken and incubated at room temperature for $2 \mathrm{~h}$. A positive result was indicated by formation of a uniform layer of coagulant over the surface of the well. On the other hand, a negative test result was indicated by the formation of a discrete "button" at the bottom of the well. Hemagglutination activity was expressed as a titer, the reciprocal of the highest two-fold dilution exhibiting positive hemagglutination. The assay was carried out in duplicate for each test solution.

\section{Hemagglutination-inhibition test}

Hemagglutination-inhibition tests were carried according to the method previously described (Le Dinh Hung et al., 2009) with minor modification. Briefly, first, $25 \mu \mathrm{L}$ amounts of serially two-fold dilutions of sugar or glycoprotein were prepared in TBS containing $20 \mathrm{mM} \mathrm{CaCl}_{2}$. To each well, an equal volume of a lectin solution (4 doses of agglutination) prepared in TBS containing $20 \mathrm{mM}$ $\mathrm{CaCl}_{2}$ was added, and the plate was mixed gently and allowed to stand at room temperature for $1 \mathrm{~h}$. Finally, $25 \mu \mathrm{L}$ of a $2 \%$ suspension of trypsin-treated human A erythrocytes was added to each well, and the plate was gently shaken and incubated for a further $1 \mathrm{~h}$. Inhibition was observed macroscopically and inhibition activity was expressed as the lowest concentration of sugar or glycoprotein. The assay was performed in duplicate per sugar and glycoprotein.

\section{Preparation of trypsin-treated porcine stomach mucin}

Porcine stomach mucin $(10 \mathrm{mg})$ was dissolved in $5 \mathrm{~mL}$ of $50 \mathrm{mM}$ TBS (pH 7.5). Trypsin (5 mg) was added to the sample and the solution obtained was incubated at $37^{\circ} \mathrm{C}$ for $24 \mathrm{~h}$. Treated PSM was heated to $100^{\circ} \mathrm{C}$ for $30 \mathrm{~min}$ then cooled (final reaction volumes were $10 \mathrm{~mL}$ ) and further used as inhibitor.

\section{Effects on hemagglutination activity of divalent cations, $\mathrm{pH}$, and temperature}

Effects on hemagglutination activity of divalent cations, $\mathrm{pH}$, and temperature were carried according to the method previously described (Le Dinh Hung et al., 2009) with minor modification. To examine the effects of divalent cations on hemagglutination activity, the lectin solution was dialyzed at $4^{\circ} \mathrm{C}$ overnight against $100 \mathrm{~mL}$ of $50 \mathrm{mM}$ EDTA followed by dialysis against TBS, $\mathrm{pH}$ 7.5. The hemagglutination activity was determined in the absence or presence of $\mathrm{CaCl}_{2}$. To examine the effect of temperature, each the lectin solution was treated at various temperatures $\left(30-100^{\circ} \mathrm{C}\right)$ for $30 \mathrm{~min}$, then immediately cooled on ice, and hemagglutination activity was determined as above. To examine the effect of $\mathrm{pH}$, each the lectin solution was dialyzed at $4^{\circ} \mathrm{C}$ overnight against $100 \mathrm{~mL}$ of $50 \mathrm{mM}$ buffers of various $\mathrm{pH}$ from 3 to 10 and then dialyzed against $150 \mathrm{mM} \mathrm{NaCl}$ solution containing $100 \mathrm{mM} \mathrm{CaCl}_{2}$ to eliminate the $\mathrm{pH}$ effect. Hemagglutination activity was determined with trypsin-treated human A erythrocytes. The assay was carried out in triplicate for each test solution.

\section{Determination of protein content}

Protein contents were determined by the method of Lowry et al. (1951) using bovine serum albumin as a standard. Absorbance at $280 \mathrm{~nm}$ was also used to estimate protein contents in fractions of chromatography.

\section{Determination of molecular mass}

The molecular mass of purified lectin was determined by sodium dodecyl sulfatepolyacrylamide gel electrophoresis (SDS-PAGE). Briefly, the samples for SDS-PAGE were denatured at $100^{\circ} \mathrm{C}$ for $5 \mathrm{~min}$ with or without $2 \%$ 2mercaptoethanol and then electrophored using a $10 \%$ gel (Laemmli, 1970). After electrophoresis, the gel was stained with Coomassie Brilliant Blue R-250 for proteins. The molecular mass of the native lectin was measured by passing it through the Sephacryl S-200 $(1.6 \times 60 \mathrm{~cm})$ column in TBS buffer, $\mathrm{pH}$ 7.5. The standard proteins used were phosphorylase B (94 $\mathrm{kDa})$, BSA $(67 \mathrm{kDa})$, ovalbumine $(45 \mathrm{kDa})$ and carbonic anhydrase $(30 \mathrm{kDa})$.

\section{Antibacterial activity}

Antibacterial activity was determined according to the method of Charungchitrak et al. (2011). Bacteria, Vibrio alginolyticus, $V$. harveyi and $V$. parahaemolyticus obtained from Research Institute for Aquaculture No. 3, VietNam, were grown in LB broth (10 g bacto-tryptone, $5 \mathrm{~g}$ bacto-yeast extract, $10 \mathrm{~g} \mathrm{NaCl}, 1 \mathrm{~L} \mathrm{H}_{2} \mathrm{O}, \mathrm{pH} 7 \cdot 0$ ) and shaken at $200 \mathrm{rpm}$ for $16-18 \mathrm{~h}$ at $37^{\circ} \mathrm{C}$. Cells were collected, washed three times with $0.15 \mathrm{M} \mathrm{NaCl}$ solution and converted to colony forming units $\left(10^{5}-10^{6} \mathrm{CFU} \mathrm{mL}^{-1}\right)$. Serial two-fold dilutions of an original solution of SFL $\left(100 \mu \mathrm{g} \mathrm{mL}^{-1}\right)$ were prepared in TBS containing 20 
$\mathrm{mM} \mathrm{CaCl} 2$ in test tubes. To each dilution, a $100 \mu \mathrm{L}$ of each bacterial suspension $\left(10^{5}-10^{6} \mathrm{CFU} \mathrm{mL} \mathrm{m}^{-1}\right)$ was added, and the mixtures were gently shaken and incubated at $37^{\circ} \mathrm{C}$ for $24 \mathrm{~h}$. As a positive reference using ampicillin solution $\left(1000 \mu \mathrm{g} \mathrm{mL}-^{1}\right)$ and negative control without both lectin and ampicillin using TBS containing $20 \mathrm{mM} \mathrm{CaCl}$, all was examined in the same way. After incubation, the turbidity of reaction solutions was measured at 600 $\mathrm{nm}$ as the index of bacterial growth. The bacterial growth in the presence of SFL and ampicillin was compared to that in a control. The inhibition activities of SFL at various concentrations were determined as the ratio (\%) to that of ampicillin $\left(1000 \mu \mathrm{g} \mathrm{mL}^{-1}\right)$ and expressed as an efficient concentration $\left(\mathrm{EC}_{50}\right)$ relative to the inhibition activity of ampicillin at $1000 \mu \mathrm{g} \mathrm{mL} \mathrm{m}^{-1}$. All assays were carried out in triplicate.

\section{RESULTS AND DISCUSSION}

\section{Extraction and purification of lectin}

The lectin from crude extract of the marine sponge $S$. flexibilis was recovered as a precipitate with $80 \%$ cold ethanol and showed strong hemagglutination activity towards trypsin- and papain-treated human A erythrocytes in TBS buffer containing $20 \mathrm{mM} \mathrm{CaCl}_{2}$, whereas it did not agglutinate erythrocytes of native or enzyme treated rabbit and human $\mathrm{B}$ and $\mathrm{O}$ blood types (Table 1).

The precipitate gave a single active peak in ion exchange chromatography on DEAE Sepharose fast flow column (Figure 1a). The active peak was further separated into two peaks in gel chromatography on a Sephacryl S-200 column. The first peak (I) exhibited strong hemagglutination activity, whereas the second peak (II) showed no activity (Figure 1b). Thus, the purified lectin was designated as SFL. The results of purification are summarized in Table 2.

\section{Physical and chemical properties of SFL}

SFL gave a band of $64 \mathrm{kDa}$ in the absence of a reducing agent ( $\beta$-mercaptoethanol) and consisted of two identical subunits of $32 \mathrm{kDa}$ in reducing condition (Figure 2a). The native molecular mass of SFL was estimated to be $65 \mathrm{kDa}$ by gel filtration (Figure 2b). Thus, the lectin was a dimeric rotein composed of two identical subunits of $32 \mathrm{kDa}$, which is linked by a disulfide bond.

Table 1. Hemagglutination activity of the precipitated fraction from the crude extract of the marine sponge $S$. flexibilis. The hemagglutination activity is expressed as a titer that is the reciprocal of the highest two-fold dilution exhibiting positive agglutination.

\begin{tabular}{|c|c|c|c|c|c|c|c|c|c|c|c|c|c|c|c|c|c|c|c|c|c|}
\hline \multicolumn{22}{|c|}{ Hemagglutination titer with erythrocytes (H.U./mL) } \\
\hline \multicolumn{5}{|c|}{ Rabbit } & \multicolumn{5}{|c|}{ Human A } & \multicolumn{6}{|c|}{ Human B } & \multicolumn{6}{|c|}{ Human $\mathrm{O}$} \\
\hline \multicolumn{2}{|r|}{ TBS } & \multicolumn{3}{|c|}{$\mathrm{TBS}+\mathrm{Ca}$} & \multicolumn{3}{|c|}{ TBS } & \multicolumn{2}{|c|}{$\mathrm{TBS}+\mathrm{Ca}$} & \multicolumn{3}{|c|}{ TBS } & \multicolumn{3}{|c|}{$\mathrm{TBS}+\mathrm{Ca}$} & \multicolumn{3}{|c|}{ TBS } & \multicolumn{3}{|c|}{$\mathrm{TBS}+\mathrm{Ca}$} \\
\hline$\overline{\mathrm{N}^{\mathrm{a}}}$ & $\mathrm{T}^{\mathrm{b}} \mathrm{P}^{\mathrm{c}}$ & $\bar{N}$ & $\mathrm{~T}$ & $P$ & $\bar{N}$ & $\mathrm{~T}$ & $P$ & $\overline{\mathrm{N}}$ & $\mathrm{T}$ & $\bar{N}$ & $\mathrm{~T}$ & $P$ & $\bar{N}$ & $\mathrm{~T}$ & $P$ & $\bar{N}$ & $\mathrm{~T}$ & $P$ & $\bar{N}$ & $\mathrm{~T}$ & $P$ \\
\hline$-{ }^{d}$ & $-\quad-$ & - & - & - & 2 & 2 & 2 & 4 & 128128 & - & - & - & - & - & - & - & - & - & - & - & - \\
\hline
\end{tabular}

${ }^{a}$ Native erythrocytes. ${ }^{b}$ Trypsin-treated erythrocytes. ${ }^{\mathrm{C}}$ Papain-treated erythrocytes. ${ }^{\mathrm{d}}$ No hemagglutination. - TBS: $20 \mathrm{mM}$ Tris$\mathrm{HCl}, 0.15 \mathrm{M} \mathrm{NaCl}, \mathrm{pH} 7.5$ buffer. - TBS+Ca: $20 \mathrm{mM}$ Tris-HCl, $0.15 \mathrm{M} \mathrm{NaCl}, \mathrm{pH} 7.5$ buffer containing $20 \mathrm{mM} \mathrm{CaCl}_{2}$.

Table 2. Summary of purification of lectin from the marine sponge S. flexibilis.

\begin{tabular}{|c|c|c|c|c|c|}
\hline $\begin{array}{l}\text { Extraction and } \\
\text { purification step }\end{array}$ & $\begin{array}{l}\text { Protein } \\
(\mathrm{mg})\end{array}$ & $\begin{array}{c}\text { Total activity }^{\mathrm{a}} \\
\text { H.U./mL }\end{array}$ & $\begin{array}{c}\text { Specific activity }^{b} \\
\text { H.U/mg }\end{array}$ & $\begin{array}{l}\text { Yield } \\
(\%)\end{array}$ & $\begin{array}{l}\text { Purification } \\
\text { factor }\end{array}$ \\
\hline Extraction & 381.9 & 3040 & 7.9 & 100 & 1 \\
\hline Ethanol precipitation & 46.8 & 2816 & 60.2 & 92.6 & 7.6 \\
\hline lon exchange & 10.4 & 896 & 86.2 & 29.5 & 10.9 \\
\hline Gel filtration & 2.9 & 332 & 114.4 & 10.9 & 14.5 \\
\hline
\end{tabular}

${ }^{\mathrm{a}}$ Inverse of the highest dilution still causing agglutination of trypsin-treated human A erythrocytes. ${ }^{\mathrm{b}}$ Hemagglutination units per mg of protein. 

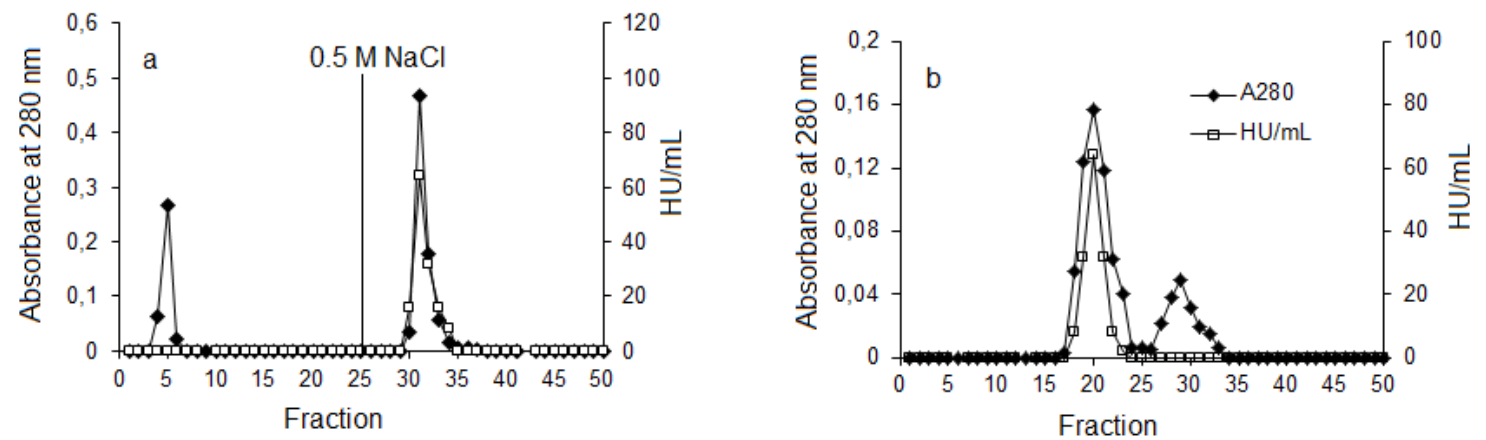

Figure 1. (a) lon-exchange chromatography of the precipitate fraction obtained from crude extract of the marine sponge Stylissa flexibilis on a DEAE Sepharose fast flow column. The column $(1.6 \times 20 \mathrm{~cm})$ was equilibrated with $50 \mathrm{mM}$ Tris- $\mathrm{HCl}$ buffer, $\mathrm{pH} 7.5$, lectin was eluted with $0.5 \mathrm{M} \mathrm{NaCl}$ in the equilibration buffer (lectin-containing fractions are indicated). (b) Gel chromatography on a Sephacryl S-200 column $(1.6 \times 60 \mathrm{~cm})$ of the active peak obtained by ion-exchange chromatography. The column was eluted with $50 \mathrm{mM}$ Tris- $\mathrm{HCl}, 150 \mathrm{mM} \mathrm{NaCl}$ buffer, $\mathrm{pH} 7.5$ at a flow rate of $0.8 \mathrm{~mL} \mathrm{~min}^{-1}$. Fractions were collected and measured at absorbance of $280 \mathrm{~nm}(-)$ for protein and for hemagglutination activity with trypsin-treated type A erythrocytes ( $-\square-$ ). HU hemagglutination unit.
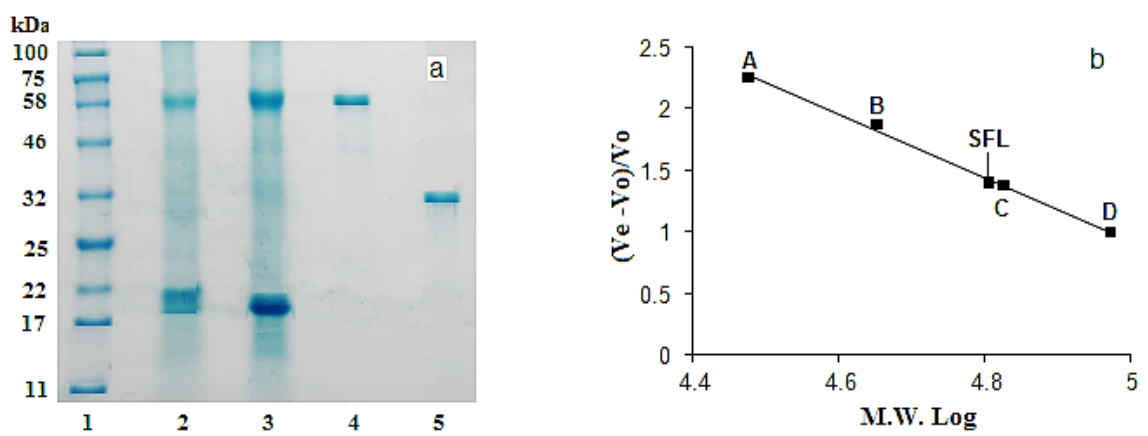

Figure 2. (a) SDS-PAGE of the lectin isolated from the marine sponge S. flexibilis. SDS -PAGE was carried using a $10 \%$ polyacrylamide gel. Protein bands were stained with Coomassie Brilliant blue R-250 reagent. Lane 1 protein marker (New England BioLabs Inc); lane 2, a $80 \%$ ethanol precipitate; lane 3, active fractions obtained from ion-exchange chromatography; lane 4, active fractions obtained by gel filtration in non-reducing condition; lane 5 , active fractions obtained by gel filtration in reducing condition by $\beta$-mercaptoethanol. (b) Determination of molecular weight of SFL by gel filtration on Sephacryl S-200 column. Protein molecular weight standards were: (A) carbonic anhydrase (30 kDa), (B) ovalbumine (45 $\mathrm{kDa})$, (C) bovine serum albumin $(67 \mathrm{kDa})$ and $(\mathrm{D})$ phosphorylase $\mathrm{B}(94 \mathrm{kDa})$.
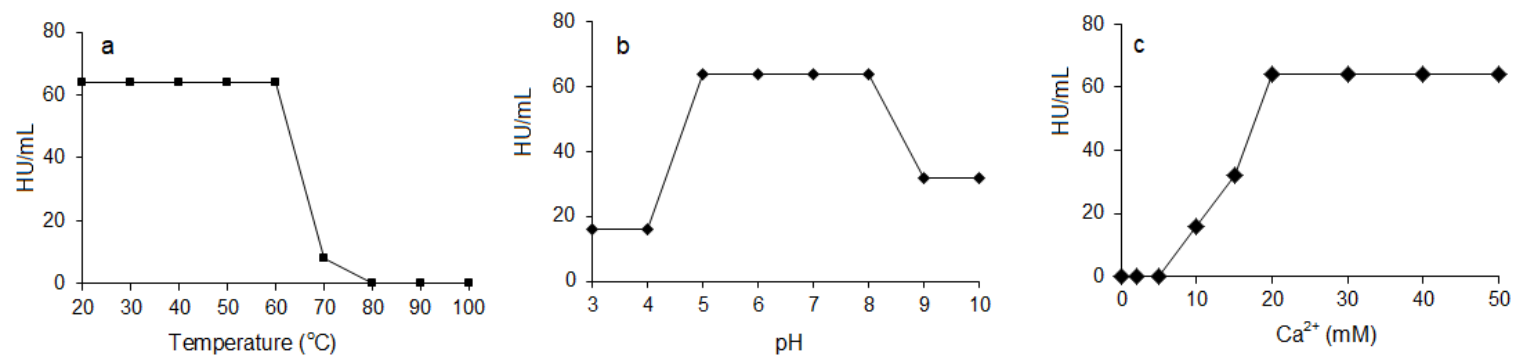

Figure 3. (a) The effects of temperature, (b) $\mathrm{pH}$ and (c) $\mathrm{CaCl}_{2}$ on hemagglutination activities of lectin.

SFL was relatively thermostable because their activities were unchanged after incubation at $60^{\circ} \mathrm{C}$ for $30 \mathrm{~min}$; however, the activities gradually decreased as incubation temperature exceeded $60^{\circ} \mathrm{C}$ (Figure 3a). The activities of SFL were stable in a range of $\mathrm{pH}$ from 5 to 8 (Figure $3 b$ ) and was dependent on the 
presence of $\mathrm{CaCl}_{2}$ as evidenced by complete activity loss in the presence of EDTA, and the addition of $\mathrm{Ca}^{2+}$ ions regains the activity of lectin (Figure 3c), indicating that SFL should be included in the C-type lectin family. The dependence on presence of divalent cations for biological activity has also been reported for many lectins from marine sponges, such as $\mathrm{AaL}$ from Aplysina archeri and AlL from Aplysina lacunose (Miarons, Fresno, 2000), AvL from Aphrocallistes vastus (Gundacker et al., 2001), CvL from Cliona varians (Moura et al., 2006) and PsL from Pellina semitubulosa (Engel et al., 1992).

\section{Carbohydrate-binding specificity}

Carbohydrate-binding specificity of SFL was examined by hemagglutination-inhibition test. Hemagglutination activity of SFL was inhibited by monosacc

Inhibition by D-galactose has been indicated for lectins from marine sponges, such as lectins from $A$. vastus (Gundacker et al., 2001), Axinella dissimilis (Bretting et al., 1981b), Cinachyrella alloclada (Atta et al., 1989), C. varians (Moura et al., 2006), Desmapsama anchorata (Atta et al., 1990), Halichondria okadai (Kawsar et al., 2008), $H$. panicea (Kamiya et al., 1990), Haliclona cratera
(Pajic et al., 2002), P. semitubulosa (Engel et al., 1992), Axinella polypoides (Bretting, Königsmann, 1979), Chondrilla nucula (Schröder et al., 1990), A. archeri and A. lacunose (Miarons, Fresno, 2000), Axinella corrugate (Dresch et al., 2012) and H.okadai (Kawsar et al., 2011). Lectins with affinityfor galactose appear to have important roles in modulating immune responses in marine animals (Yousif et al., 1994; Mistry et al., 2001; Kurata, Hatai, 2002). Activities of SFL were strongly inhibited by asialo-fetuin and asialo-porcine stomatch mucin. Inhibition by asialo-fetuin has been evidenced for lectins from marine sponges, such as HOL-30 from Halichondria okadai (Kawsar et al., 2008) and HcL from Haliclona cratera (Pajic et al., 2002). On the other hand, inhibition by porcine stomatch mucin and their asialo derivatives bearing O-glycans that is related to galactose binding specificity reported for many lectins from marine sponges, such as CauL from Craniella australiensis (Xiong et al., 2006), Halilectin 2 and Halilectin 3 from Haliclona caerulea (Carneiro et al., 2013a, 2013b), HpL from H. panicea (Kamiya et al., 1990), ACL-II from A. corrugata (Dresch et al., 2012), HcL from Haliclona crater (Pajic et al., 2002) and AaL from $A$. archeri (Miarons, Fresno, 2000).

Table 3. Hemagglutination-inhibition test of SFL with carbohydrates and glycoproteins.

\begin{tabular}{|c|c|c|c|}
\hline Carbohydrates & $\begin{array}{l}\text { Minimum inhibitory } \\
\text { concentration (mM) }\end{array}$ & Glycoproteins & $\begin{array}{l}\text { Minimum inhibitory } \\
\text { concentration }\left(\mu \mathrm{g} \mathrm{mL}^{-1}\right)\end{array}$ \\
\hline D-Mannose & $a_{-}$ & Porcine stomach mucin & 500 \\
\hline L-Fucose & - & $\begin{array}{l}\text { Trypsin-treated } \\
\text { stomach mucin }\end{array}$ & 500 \\
\hline N-Acety-D-Mannosamine & - & Asialo-Fetuin & 62.5 \\
\hline N-Acetyl-D-Glucosamine & - & Transferin & - \\
\hline N-Acetyl-D-Galatosamine & - & Asialo-Transferin & - \\
\hline N-Acetyl neuraminic acid & - & Yeast Mannan & - \\
\hline
\end{tabular}

Trypsin-treated A blood group human erythrocytes were used. Inhibitory activity is expressed as the minimum inhibitory concentration of sugars that is required to inhibit completely the hemagglutination activity (4 doses of agglutination). Dashes indicate no inhibitory activity at the concentration for $100 \mathrm{mM}$ for monosaccharide and $2000 \mu \mathrm{g} \mathrm{mL} \mathrm{mor}^{-1}$ glycoproteins.

\section{Antibacterial activity}

SFL obtained from marine sponge $S$. flexibilis significantly inhibited the growth at more than 1.56 $\mu \mathrm{g} \mathrm{mL} \mathrm{m}^{-1}$ for both $V$. parahaemolyticus and $V$. alginolyticus, whereas it did not affect the growth of $V$. harveyi even at $100 \mu \mathrm{g} \mathrm{mL} \mathrm{m}^{-1}$. The highest concentration of SFL $\left(100 \mu \mathrm{g} \mathrm{mL}^{-1}\right)$ suppressed the growth of $V$. alginolyticus to $78 \%$ and of $V$. parahaemolyticus to $74 \%$ in comparison to that in the control without lectin solution. The degrees of inhibition at various concentrations of SFL to that of ampicillin at $1000 \mu \mathrm{g} \mathrm{mL} \mathrm{m}^{-1}$ were plotted as the inhibition ratios relative to ampicillin. The antibacterial activity of SFL was comparable to that 
of ampicillin with a relative $\mathrm{EC}_{50}$ of $6.45 \mu \mathrm{g} \mathrm{mL}^{-1}$ for $V$. parahaemolyticus and $5.95 \mu \mathrm{g} \mathrm{mL} \mathrm{m}^{-1}$ for $V$. alginolyticus (Figure 4).

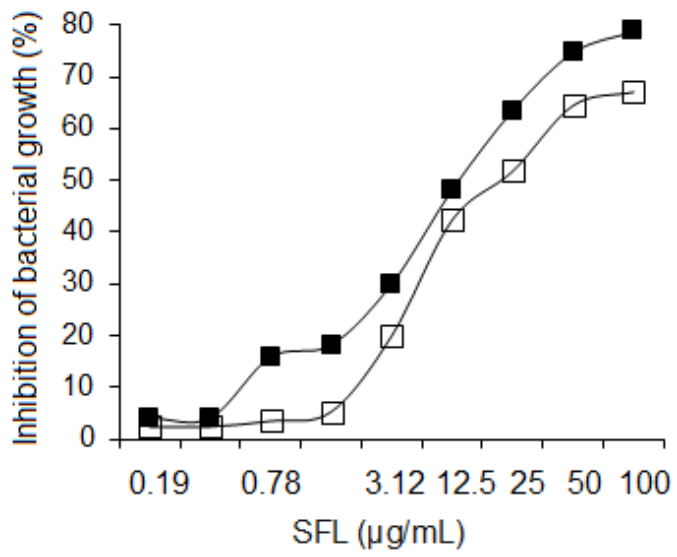

Figure 4. Antibacterial activity and inhibition of antibacterial activity. The growth of $V$. alginolyticus and $V$. parahaemolyticus after incubation at $37^{\circ} \mathrm{C}$ for $24 \mathrm{~h}$ was measured at absorbance of $600 \mathrm{~nm}$. The inhibitory effect of SFL against the bacterial growth was expressed in percentage where the inhibition effect of $1000 \mu \mathrm{g} \mathrm{mL}$ ampicillin (a positive control) was hundred percent and that of non-lectin or -ampicillin supplemented solution (a negative control) was zero percent. SFL treatments with $V$. alginolyticus ( - ) and $V$. parahaemolyticus ( $\square-$ ).

It has also been reported that several lectins isolated from marine sponges can inhibit the growth of various bacterial pathogens and fungi (Schröder et al., 2003; Moura et al., 2006; Kawsar et al., 2011). However, there seems to be not reported yet for the activities of lectin from marine sponges against shrimp and fish pathogens. SFL inhibited the growth of shrimp pathogenic bacteria, $V$. alginolyticus and $V$. parahaemolyticus, suggesting that these Vibrios have asialo-PSM like structure on the cells, which might respond as a receptor(s) for SFL, while $V$. harveyi do not have such structure on their cell surfaces. Almost all microorganisms express surface-exposed carbohydrates, which might respond as a receptor(s) for lectin. Thus, the mode of interaction between lectins with bacteria varies significantly among lectins from various organisms, mainly depending on their carbohydrate binding specificity.

\section{CONCLUSION}

SFL, a lectin from marine sponge $S$. flexibilis, showed novel properties, including a dimeric protein composed of two identical subunits linked by a disulfide bond. Hemagglutination activity of SFL was dependent on the presence of $\mathrm{CaCl}_{2}$, indicating that SFL should be included in the C-type lectin family. SFL preferably bond to asialo derivatives of O-glycans that is related to galactose binding specificity, indicating that the terminal D-galactose residues in O-glycans were critical for lectin binding. SFL inhibited the growth of $V$. parahaemolyticus and $V$. alginolyticus. These results indicate that the marine sponge $S$. flexibilis may be a good source of a lectin that may be useful as an antibacterial agents.

Acknowledgements: This research was supported by Vietnam Academy of Science and Technology (VAST) under grant number VAST06.04/16-17.

\section{REFERENCES}

Atta AM, Barral-Netto M, Peixinho S, Sousa-Atta MLB (1989) Isolation and functional characterization of a mitogenic lectin from the marine sponge Cinachyrella alloclada. Braz J Med Biol Res 22: 379-385.

Atta AM, Menezes EP, Peixinho S, Sousa-Atta MLB (1990) Isolation of a lectin from the marine sponge Desmapsama anchorata by affinity chromatography on raffinose-Sepharose 6B. Braz J Med Biol Res 23: 191-194.

Boonsri N, Rudtanatip T, Wongprasert K (2017) Protein extract from red seaweed Gracilaria fisheri prevents acute hepatopancreatic necrosis disease (AHPND) infection in shrimp. J Appl Phycol 29: 1597-1608.

Bretting H, Königsmann K (1979) Investigations on the lectin-producing cells in the sponge Axinella polypoides (Schmidt). Cell Tissue Res 201: 487-497.

Bretting H, Phillips SG, Klumpart HJ, Kabat EAA (1981a) Mitogenic lactose binding lectin from the sponge Geodia cydonium. J Immunol 127: 1652-1658.

Bretting H, Donadey C, Vacelet J, Jacobs G (1981b) Investigation on the occurrence of lectins in marine sponges with special regard to some species of the family Axinellidae. Comp Biochem Physiol B 70: 69-76.

Carneiro RF, de Melo AA, Nascimento FEPD, Simplicio CA, Nascimento KSD,

Rocha BAMD, Saker-Sampaio S, Moura RDM, Mota SS, Cavada BS (2013a) Halilectin 1 (H-1) and Halilectin 2 (H2): Two new lectins isolated from the marine sponge Haliclona caerulea. J Mol Recognit 26: 51-58.

Carneiro RF, de Melo AA, de Almeida AS, Moura Rda M, Chaves RP, de Sousa RP, Nascimento KS, Sampaio SS, Lima JP, Cavada BS (2013b) H-3, a new lectin from the marine sponge Haliclona caerulea: Purification and mass spectrometric characterization. Int J Biochem Cell Biol 45: 2864-2873. 
Charungchitrak S, Petsom A, Sangvanich P, Karnchanatat A (2011) Antifungal and antibacterial activities of lectin from the seeds of Archidendron jiringa Nielsen. Food Chem 126: 1025-1032.

Dresch RR, Zanett, GD, Lerner C, Mothes B, Trindade VMT, Henriques AT, Vozári-Hampe MM (2008) ACL-I, a lectin from the marine sponge Axinella corrugata: isolation, characterization and chemotactic activity. Comp Biochem Physiol C 148: 23-30.

Dresch RR, Lerner CB, Mothes B, Trindade VMT, Henriques AT, Vozári-Hampe MM (2012) Biological activities of ACL-I and physicochemical properties of ACL-II, lectins isolated from the marine sponge Axinella corrugate. Comp Biochem Physiol B 161: 365-370.

Engel M, Bachmann M, Schröder HC, Rinkevich B, Kljajic Z, Uhlenbruck G (1992) A novel galactose- and arabinose-specific lectin from the sponge Pellina semitubulosa: Isolation, characterization and immunobiological properties. Biochimie 74: 527-537.

FAO (2013) Report of the FAO/MARD Technical Workshop on Early Mortality Syndrome (EMS) or Acute Hepatopancreatic Necrosis Syndrome (AHPNS) of Cultured Shrimp (under TCP/VIE/3304). Hanoi, VietNam, on 25-27 June 2013. FAO Fisheries and Aquaculture Report No. 1053. Rome. 54 pp.

Gardères J, Bourguet-Kondracki ML, Hamer B, Batel R, Schröder HC, Müller WEG (2015) Porifera Lectins: Diversity, Physiological Roles and Biotechnological Potential. Mar Drugs 13: 5059-5101.

Gundacker D, Leys SP, Schröder HC, Müller IM, Müller WEG (2001) Isolation and cloning of a C-type lectin from the hexactinellid sponge Aphrocallistes vastus: A putative aggregation factor. Glycobiology 11: 21-29.

Kamiya H, Muramoto K, Goto R (1990) Purification and characterization of a lectin from a marine sponge Halichondria panicea. Bull Jap Soc Sci Fish 56: 1159.

Kawsar SMA, Fujii Y, Matsumoto R, Ichikawa T, Tateno H, Hirabayashi J, Yasumitsu H, Dogasaki C, Hosono M, Nitta K, Hamako J, Matsui T, Ozeki Y (2008) Isolation, purification, characterization and glycan-binding profile of a D-galactoside specific lectin from the marine sponge, Halichondria okadai. Comp Biochem Physiol B 150: 349357.

Kawsar SMA, Mamun SMA, Rahman MDS, Hidetaro Y, Ozeki Y (2011) In vitro antibacterial and antifungal effects of a $30 \mathrm{kDa}$ D-galactoside-specific lectin from the desmosponge Halichondria okadai. Int J Biol Life Sci 7: 31-37.

Kurata O, Hatai K (2002) Activation of carp leukocytes by a galactose binding protein from Aphanomyces piscicida. Dev Comp Immunol 26: 461-469.
LaemmLi UK (1970) Cleavage of structural proteins during the assembly of the head of bacteriophage T4. Nature 227: 680-685.

Le Dinh Hung, Hori K, Huynh Quang Nang (2009) Screening and preliminary characterization of hemagglutinins in Vietnamese marine algae. $J$ Appl Phycol 21: 89-97.

Le Dinh Hung, Hirayama M, Bui Minh Ly, Hori K (2015a) Purification, primary structure, and biological activity of high-mannose $\mathrm{N}$-glycan-specific lectin from the cultivated Eucheuma denticulatum. J Appl Phycol 27: 1657-1669.

Le Dinh Hung, Hirayama M, Bui Minh Ly, Hori K (2015b) Biological activity, cDNA cloning and primary structure of lectin KSA-2 from the cultivated red alga Kappaphycus striatum (Schmitz) Doty ex Silva. Phytochem Lett 14: 99-105.

Liao WR, Lin JY, Shieh WY, Jeng WL, Huang R (2003) Antibiotic activity of lectins from marine algae against marine vibrios. $J$ Ind Microbiol Biotechnol 30: 433-439.

Lowry OH, Rosebrough NJ, Farr AL, Randall RJ (1951) Protein measurement with the Folin phenol reagent. J Biol Chem 193: 265-275.

Marhual NP, Das BK, Sadique M, Swain AK, Mishra BK, Maiti NK (2010) Molecular identification and typing of Vibrio alginolyticus and Vibrio parahaemolyticus strains isolated from black tiger shrimp Penaeus monodon. $J$ Aquaculture in Trop 25: 25-33.

Medeiros DS, Medeiros TL, Ribeiro JKC, Monteiro NKV, Migliolo L, Uchoa AF, Vasconcelos IM, Oliveira AS (2010) A lactose specific lectin from the sponge Cinachyrella apion: Purification, characterization, Nterminal sequences alignment and agglutinating activity on Leishmania promastigotes. Comp Biochem Physiol B 155: 211-216.

Miarons PB, Fresno M (2000) Lectins from tropical sponges. Purification and characterization of lectins from genus Aplysina. J Biol Chem 275: 29283-29289.

Mistry AC, Honda S, Hirose S (2001) Structure, properties and enhanced expression of galactose-binding C-type lectins in mucous cells of gills from freshwater Japanese eels (Anguilla japonica). Biochem J 360: 107-115.

Moura RM, Queiroz AFS, Fook, JMS, Dias ASF, Monteiro NKV, Ribeiro JKC, Moura GEDD, Macedo LLP, Santos EA, Sales MP (2006) CvL, a lectin from the marine sponge Cliona varians: isolation, characterization and its effects on pathogenic bacteria and Leishmania promastigotes. Comp Biochem Physiol A 145: 517-523.

Pajic I, Kljajic Z, Dogovic N, Sladic D, Juranic Z, Gasic MJ (2002) A novel lectin from the sponge Haliclona cratera: isolation, characterization and biological activity. Comp Biochem Physiol C 132: 213-221. 
Queiroz AFS, Moura RM, Ribeiro JKC, Lyra IL, Cunha DCS, Santos EA, De-Sales MP (2008) Pro-inflammatory effect in mice of $\mathrm{CvL}$, a lectin from the marine sponge Cliona varians. Comp Biochem Physiol C 147: 216-221.

Queiroz AF, Silva RA, Moura RM, Dreyfuss JL, ParedesGamero EJ, Souza AC, Tersariol IL, Santos EA (2009) Growth inhibitory activity of a novel lectin from Cliona varians against K562 human erythroleukemia cells. Cancer Chemother Pharmacol 63: 1023-1033.

Santi-Gadelha T, Gadelha CAA, Aragão KS, Oliveira CC, Mota MRL, Gomes RC (2006) Purification and biological effects of Araucaria angustifolia (Araucariaceae) seed lectin. Biochem Biophys Res Commun 350: 1050-1055.

Schröder HC, Kljajic Z, Weiler BE, Gasic M, Uhlenbruck G, Kurelec B, Müller WEG (1990) The galactose-specific lectin from the sponge Chondrilla nucula displays antihuman immunodeficiency virus activity in vitro via stimulation of the $\left(2^{\prime}-5^{\prime}\right)$ oligoadenylate metabolism. Antivir Chem Chemother 1: 99-105.

Schröder HC, Ushijima H, Krasko A, Gamulin V, Thakur NL, Diehl-Seifert B, Müller IM (2003) Emergence and disappearance of an immune molecule, an antimicrobial lectin, in basal metazoa. A tachylectin-related protein in the sponge Suberites domuncula. J Biol Chem 278: 3281032817.

Sharon N, Lis H (2003) Lectins, second ed. Kluwer Academic Publishers, The Netherlands.

Tracy HH, Dongying W, Jonathan AE, Patricia AS (2007) Sequence characterization and comparative analysis of three plasmids isolated from environmental Vibrio spp. Appl Environ Microbiol 73: 7703-7710.

Xiong C, Li W, Liu H, Zhang W, Dou J, Bai X, Du Y (2006) A normal mucin binding lectin from the sponge Craniella australiensis. Comp Biochem Physiol C 143: 916.

Yousif AN, Albright LJ, Evelyn TPT (1994) Purification and characterization of a galactose-specific lectin from eggs of coho salmon Oncorhynchus kisutch and its interaction with bacterial fish pathogens. Dis Aquat Org 20: $127-136$.

Zorrilla I, Arijo S, Chabrillon M, Diaz P (2003) Vibrio species isolated from diseased farmed sole (Solea senegalensis, Kaup) and evaluation of the potential virulence role of their extracellular products. J Fish Dis 26: $103-108$.

\section{ĐẶC TÍNH CỦA LECTIN DẠNG C TÙ̉ HẢI MIÊN (STYLISSA FLEXIBILIS)}

\section{Lê Đình Hùng, Đinh Thành Trung}

Viện Nghiên cưu và Úng dụng Công nghệ Nha Trang, Viện Hàn lâm Khoa học và Công nghệ Việt Nam

\section{TÓM TẮT}

Một lectin từ hải miên Stylissa flexibilis, được đặt tên là SFL, đã được tinh chế qua các bước kết tủa bằng ethanol, sắc ký trao đổi ion trên cột $\mathrm{DEAE}$ Sepharose và sắc ký lọc gel Sephacryl S-200. SFL là một glycoprotein dạng dimer 2 tiểu đơn vị $32 \mathrm{kDa}$ gắn cầu nối disulfide, có khối lượng phân tử là $64 \mathrm{kDa}$ với SDSPAGE và là $65 \mathrm{kDa}$ với sắc ký lọc gel trên cột Sephacryl S-200. Lectin này có đặc tính ưu tiên gây ngưng kết hồng cầu người nhóm máu $\mathrm{A}$ được xử lý enzyme, trái lại nó không ngưng kết với bất kỳ dạng hồng cầu thỏ, hồng cầu nhóm máu người $\mathrm{B}$ và $\mathrm{O}$, ngay cả khi hồng cầu được xử lý enzyme. Hoạt tính của lectin bị ức chế mạnh bởi đường đơn, $\mathrm{D}$-galactose và glycoproteins, asialo-porcine stomach mucin và asialo-fetuin, chỉ ra rằng lectin đặc hiệu cho $\mathrm{O}$-glycan. SFL bền trong khoảng $\mathrm{pH}$ từ 5 đến 8 , chịu được $60^{\circ} \mathrm{C}$ trong 30 phút, SFL có hoạt tính phụ thuộc vào cation hóa trị hai $\mathrm{Ca}^{2+}$ nên thuộc họ lectin dạng $\mathrm{C}(\mathrm{C}$-type). SFL có khả năng gây ngưng kết có tính phụ thuộc vào liều lượng và ức chế sự tăng trưởng vi khuẩn Vibrio alginolyticus, $V$. Parahaemolyticus gợi ý rằng lectin này gây ra sự dính kết các tế bào thông qua việc gắn lên các thụ thể đích trên bề mặt của vi khuẩn Vibrio. Như vậy, SFL có thể được xem là một nguồn lectin tốt để dùng làm mẫu dò đối với carbohydrate và làm chất kháng vi khuẩn.

Từ khóa: Stylissa flexibilis, đặc tính liên kết carbohydrat, Hải miên, hoạt tính kháng khuẩn, lectin 